\title{
Studi Komparasi Implementasi Kurikulum KTSP dengan Kurikulum 2013 Mapel Pendidikan Agama Islam pada Kajian Standar Kompetensi
}

\author{
Jaka Rebawa \\ SMA N 1 Salatiga Kota Salatiga \\ Email: jakarebawa20@gmail.com
}

\begin{abstract}
Abstrak
Ketegasan kurikulum dan implementasinya sangat dibutuhkan untuk membenahi kinerja pendidikan yang jauh tertinggal. Indonesia di era reformasi, telah mengalami tiga perubahan kurikulum, yaitu: KBK, KTSP dan K. 2013. Dari perkembangan kurikulum yang terjadi kemungkinan adanya perbedaan implemensi pada standar kompetensinya, maka hal ini perlu dikaji. Jenis penelitian ini kualitatif dengan pendekatan fenomenologis. Objek studi pada implementasi KTSP dan K. 2013 di SMA N 1 Salatiga, SMA Islam Sudirman dan SMA N 1 Tengaran. Pengumpulan data menggunakan observasi, dokumentasi dan wawancara dengan analisis induksi analitik. Hasil Penelitian: Implementasi KTSP PAI pada SK di SMAN 1 Salatiga, SMA Islam Sudirman Ambarawa dan SMAN 1 Tengaran Kabupaten Semarang tahun pelajaran 2013/2014 telah terlaksana dengan baik karena telah mengikuti struktur kurikulum yang ditentukan, Implementasi K. 2013 Mapel PAI pada SK terimplementasi baik, Standar Isi diturunkan dari SKL melalui KI. Perbedaan mendasar pada SK, SI dan SKL menjadi acuan utama pengembangan KTSP, sedangkan K. 2013 SKL dan KI menjadi acuan utama. Faktor penghambat adalah dalam memberikan penilaian, media riil, waktu, penyusunan RPP, siswa kesulitan materi. Penanganannya dengan cara melengkapi sarpras, mengirim guru dalam pelatihan, menyederhanakan materi pelajaran, memberikan jam tambahan dan konsultasi akademik pada siswa.
\end{abstract}


Curriculum assertiveness and its implementations are needed to improve educational performance that is far behind. Indonesia in the reform era, has undergone three changes of curriculum, namely: $C B C, S B C$ and 2013 Curriculum. Fronm there, it is possible that there are differences in the implementations and competence standard, then it needs a study. it utilizes a qualitative research with phenomenological approach. The object of the study is the implementation of SBC and K., 2013 in SMA N 1 Salatiga, SMA Sudirman and SMA N 1 Tengaran. The data collection is through observation, documentation and interview with the analysis of analytic induction. the results are: the SBC implementation of PAI SK at SMAN 1 Salatiga, SMA Islam Sudirman Ambarawa and SMAN 1 Semarang 2013/2014 has performed well since they have followed the prescribed curriculum structure, K. 2013 Implementation of PAI SK is well , Content Standards is derrived from SKL through KI. The fundamental difference in SK, SI and SKL become the main reference of SBC curriculum development, whereas K. 2013 and KI become the main reference. The nhibiting factors are in providing an assessment, real media, time, preparation of lesson plans, the students' diffulty to the material. they are fixed by completing facilities, sending teachers to trainings, simplifying the materials, providing additional hours and academic advising to students.

Kata Kunci: KTSP, Kurikulum 2013, Standar Kompetensi.

\section{Pendahuluan}

Pendidikan merupakan suatu upaya mewariskan nilai, yang akan menjadi penolong dan penuntun dalam menjalani kehidupan, sekaligus untuk memperbaiki nasib dan peradaban manusia yang bisa dilakukan sejak masih dalam kandungan (Mansur, 2001: 1). Perkembangan peradaban manusia tak dapat dibayangkan bila tanpa pendidikan, mungkin saja manusia sekarang tidak akan beda dengan orang zaman dahulu, bahkan mungkin akan lebih terpuruk atau lebih rendah kualitas peradabannya. Oleh karena itu perlu menjadi kekhawatiran bersama bila 
hal senada ternyata mulai menggejala pada masyarakat. Sangat memilukan bahwa masyarakat Indonesia yang religius dewasa ini terpuruk dalam himpitan krisis dan terbelakang dalam berbagai aspek kehidupan (Mas'ud, 2004: 122).

Masyarakat madani, masyarakat yang selalu kita idam-idamkan (Imaginet Community) sebagai masyarakat yang beradab, masyarakat yang saling menghargai dan menghormati sesama, hanya dapat diwujudkan dengan pendidikan. Tentunya pendidikan yang bermutu bukan pendidikan yang asal-asalan. Pendidikan yang dilaksanakan dengan program dan perencanaan yang baik dan berdasar pada keilmuan serta budi pekerti yang luhur, sebagaimana tujuan pendidikan.

Dalam mencapai tujuan pendidikan tersebut maka diperlukan berbagai faktor dan unsur yang mendorongnya terutama kurikulum yang diterapkan atau dipakai. Kurikulum mempunyai kedudukan sentral dalam seluruh proses pendidikan. Kurikulum mengarahkan segala bentuk aktifitas pendidikan demi tercapainya tujuan-tujuan pendidikan. Kurikulum juga merupakan suatu rencana pendidikan, memberikan pedoman dan pegangan tentang jenis, lingkup dan urutan isi, serta proses pendidikan (Sukmadinata, 1999: 4). Kurikulum dalam sistem persekolahan merupakan suatu rencana yang memberi pedoman atau pegangan dalam proses kegiatan belajar mengajar.

Kurikulum yang baik harus selalu berubah dari waktu ke waktu sesuai dengan perkembangan zaman (Mulyasa, 2007: 7). Sejak tahun 2004-2005 pemerintah telah menetapkan kurikulum berbasis kompetensi (KBK), dan tahun 2007 pemerintah telah menetapkan kurikulum tingkat 
satuan pendidikan (KTSP) dan tahun 2013 ini pemerintah lagi-lagi menetapkan kurikulum 2013 yang berbasis kompetensi (kompetensi sikap, pengetahuan dan ketrampilan) sebagai kurikulum yang berlaku di Indonesia.

Dalam proses pendidikan, kurikulum merupakan alat untuk mencapai tujuan pendidikan. Tanpa kurikulum yang sesuai dan tepat akan sulit untuk mencapai tujuan dan sasaran pendidikan yang diinginkan (Hamalik, 2009: 64). Tak terkecuali pada mapel PAI dan budi pekerti yang baru terglontorkan saat ini. Di samping itu, kurikulum memberi arahan dan patokan keahlian kepada peserta didik setelah menyelesaikan suatu program pengajaran pada suatu lembaga. Oleh karena itu, wajar bila kurikulum selalu berubah dan berkembang sesuai dengan kemajuan zaman, kemajuan ilmu pengetahuan, dan teknologi yang sedang terjadi.

Kurikulum sifatnya dinamis karena selalu berubah-ubah sesuai dengan perkembangan dan tantangan zaman. Semakin maju peradaban suatu bangsa, maka semakin berat pula tantangan yang dihadapinya. Persaingan ilmu pengetahuan semakin gencar dilakukan oleh dunia internasional, sehingga Indonesia juga dituntut untuk dapat bersaing secara global demi mengangkat martabat bangsa. Oleh karena itu, untuk menghadapi tantangan yang akan menimpa dunia pendidikan kita, ketegasan kurikulum dan implementasinya sangat dibutuhkan untuk membenahi kinerja pendidikan yang jauh tertinggal dengan negaranegara maju di dunia.

Sekarang ini kelemahan-kelemahan pelaksanaan kurikulum yang sudah ada telah menjadi sorotan kritik berbagai pihak. Tidak hanya pihak 
diluar dunia pendidikan tetapi pihak-pihak didalam sendiri sudah memprihatinkan proses dan produk pengelolaan kurikulum yang dilaksanakan oleh administrator pendidikan sampai pada yang dilaksanakan oleh guru-guru di kelas. Ironisnya, Sasaran kritik hanya di tujukan kepada guru-guru, dan para administrator terlindung seolah-olah peranan dan tanggung jawabnya tidak menentukan. Jarang kedengaran kritik terhadap, misalnya kepala sekolah, pengawas (penilik) ataupun administrator atasan yang membawahinya. Diakui atau tidak, praktik dilapangan dalam implementasi lebih sulit dibanding dengan mengungkapkan pendapat dan berkomentar. Karena praktik dilapangan menghadapi langsung bergabagai faktor yang mempengaruhi proses pembelajaran.

Tidak bisa dipungkiri bahwa perubahan kurikulum selalu mengarah pada perbaikan sistem pendidikan. Perubahan tersebut dilakukan karena dianggap belum sesuai dengan harapan yang diinginkan sehingga perlu adanya revitalisasi kurikulum. Usaha tersebut mesti dilakukan demi menciptakan generasi masa depan berkarakter, yang memahami jati diri bangsanya dan menciptakan anak yang unggul, mampu bersaing di dunia internasional (Mulyasa, 2008: 37).

Dengan munculnya kurikulum 2013 banyak wacana yang berkembang tentang kurikulum 2013 ini. Ada berbagai persepsi dan kritik yang berkembang dan perlu dihargai sebagai bagian dari proses pematangan kurikulum yang sedang disusun. Selama era reformasi, ini adalah ketiga kalinya kurikulum ditelaah dan dikembangkan dalam skala nasional setelah rintisan Kurikulum Berbasis Kompetensi 2004 dan 
Kurikulum Tingkat Satuan Pendidikan 2007 maka yang terbaru saat ini muncullah kurikulum 2013.

Penelitian ini mengkaji implementasi kurikulum 2013 di SMAN 1 Salatiga, SMA Islam Sudirman Ambarawa dan SMAN 1 Tengaran Kabupaten Semarang kemudian mengkomparasikannya dengan implmentasi kurikulum 2007 (KTSP) yang pernah diterapkan di SMAN 1 Salatiga, SMA Islam Sudirman Ambarawa dan SMAN 1 Tengaran Kabupaten Semarang.

Berdasarkan latar belakang masalah di atas, maka yang menjadi fokus masalah dalam penelitian ini adalah mencari perbedaan dan kesamaan dalam pengimplementasian kurikulum 2007 dengan 2013 di SMA Negeri 1 Salatiga, SMA Islam Sudirman Ambarawa dan SMAN 1 Tengaran Kabupaten Semarang penulis rumusan sebagai berikut: 1). Bagaimana implementasi kurikulum 2007 mapel Pendidikan Agama Islam pada kajian standar kompetensi di SMAN 1 Salatiga, SMA Islam Sudirman Ambarawa dan SMAN 1 Tengaran Kabupaten Semarang tahun pelajaran 2013/2014; 2). Bagaimana implementasi kurikulum 2013 mapel Pendidikan Agama Islam pada kajian standar kompetensi di SMAN 1 Salatiga, SMA Islam Sudirman Ambarawa dan SMAN 1 Tengaran Kabupaten Semarang tahun pelajaran 2013/2014; 3). Adakah perbedaan ataupun kesamaan antara implementasi kurikulum 2007 dengan kurikulum 2013 mapel Pendidikan Agama Islam pada kajian standar kompetensi di SMAN 1 Salatiga, SMA Islam Sudirman Ambarawa dan SMAN 1 Tengaran Kabupaten Semarang tahun pelajaran 2013/2014; 4). Apa saja faktor-faktor kesulitan dan hambatan dalam 
implementasi kurikulum 2007 dengan kurikulum 2013 mapel Pendidikan Agama Islam pada kajian standar kompetensi di SMAN 1 Salatiga, SMA Islam Sudirman Ambarawa dan SMAN 1 Tengaran Kabupaten Semarang tahun pelajaran 2013/2014; 5). Bagaimana cara mengatasi faktor-faktor kesulitan dan hambatan dalam implementasi kurikulum 2007 dengan kurikulum 2013 mapel Pendidikan Agama Islam pada kajian standar kompetensi di SMAN 1 Salatiga, SMA Islam Sudirman Ambarawa dan SMAN 1 Tengaran Kabupaten Semarang tahun pelajaran 2013/2014.

\section{Metode Penelitian}

Penelitian ini termasuk jenis penelitian kualitatif yang berdasarkan studi lapangan (field research) yang bersifat studi kasus dengan mengambil objek studi pada implementasi kurikulum 2007 (KTSP) dan kurikulum 2013 di SMAN 1 Salatiga SMA Islam Sudirman Ambarawa dan SMAN 1 Tengaran Kabupaten Semarang Tahun Pelajaran 2013/2014. Dan dengan pendekatan phenomenologis, pendekatan fenomenologi berlandaskan pada empat kebenaran, yaitu kebenaran empirik sensual yang jangkauannya yaitu segala kebenaran yang dapat terlihat oleh panca indra/yang bersifat indrawi, kebenaran empirik logik yang jangkauannya yaitu segala kebenaran yang dapat dinalar oleh akal/pemikiran, kebenaran empirik etik yang jangkauannya yaitu segala kebenaran yang berdasarkan pada benar, salah, baik, buruk, dan tanggung jawab, dan kebenaran empirik transenden yang jangkauannya yaitu segala kebenaran yang didasarkan pada aturan-aturan yang ditetapkan Tuhan atau bersifat transenden. Atas dasar cara mencapai kebenaran ini, 
fenomenologi menghendaki kesatuan antara subyek peneliti dengan pendukung obyek penelitian (Muhadjir, 1996: 13).

Dalam metodologi fenomenologi, pada dasarnya hanya mengenal dua metode pengumpulan data yaitu observasi partisipan dan wawancara bebas (Muhadjir, 1996: 177). Akan tetapi sebagaimana menurut Guba dan Lincoln yang dikutip Moleong dapat mengggunakan dokumentasi sebagai metode tambahan (Moleong, 2010: 163).

Teknik analisis dalam penelitian ini menggunakan pendekatan induksi analitik. Data yang dikumpulkan kemudian dianalisis secara induksi untuk mengembangkan model deskripsi penelitian dan menghasilkan laporan deskripsi analitik, dengan langkah-langkah analisis sebagai berikut: Menelaah data yang berhasil dikumpulkan dari hasil observasi, wawancara dan dokumentasi, Mengadakan reduksi data dengan cara mengambil data yang dapat diolah lebih lanjut, Menyusun data dalam satuan-satuan yang relevan, Melakukan kategorisasi sambil melakukan pengkodean (coding), Mengadakan pemeriksaan keabsahan data, Menafsirkan data dan mengambil kesimpulan secara induktif dengan cara berfikir berdasarkan fakta-fakta khusus, kemudian diarahkan kepada penarikan kesimpulan yang bersifat umum (Sugiyono, 2002: 246).

\section{Pembahasan}

\section{Pelaksanaan Kurikulum Secara Umum}

Dari sederet penelitian yang penulis lakukan dari bulan Juli sampai dengan Oktober di SMA N 1 Salatiga, SMA Islam Sudirman Ambarawa 
dan SMA N 1 Tengaran Kabupaten Semarang tentang implementasi kurikulum KTSP dan kurikulum 2013 ditemukan oleh penulis bahwa dari SMA N 1 Salatiga mulai kepala sekolah, waka kurikulum maupun para guru sangat mendukung setiap bergulirnya kurikulum, dukungan ini diantaranya terwujud pada sikap kebijakan kepala sekolah yang pro aktif untuk mengikut sertakan para gurunya dalam pelatihan-pelatihan, workshop guna penguasaan para guru terhadap kurikulum yang ada dapat maksimal, kesiapan waka kurikulum dalam menyusun kurikulum di sekolah dan menyiapkan segala keperluan pendukung yang dibutuhkan.

Di SMA Islam Sudirman Ambarawa baik munculnya kurikulum KTSP pada tahun 2006/2007 maupun kurikulum 2013 senantiasa ditanggapi dengan positif sebagaimana penjelasan kepala sekolah, bahwa SMA Islam Sudirman Ambarawa senantiasa mendukung penuh kebijakan pemerintah tentang perubahan kurikulum, karena (lebih lanjut kepala sekolah menjelaskan) setiap ada perubahan berarti ada penyempurnaan (W/JP/GK/13-09-2014).

Di SMA N 1 Tengaran Kabupaten Semarang setiap perubahan kurikulum juga selalu di tanggapi dengan positif, dari mulai kurikulum 1975, 1984,1994, KBK, KTSP sampai kurikulum 2013 yang baru bergulir, kebijakan kepala sekolah selalu mendukung terbukti dengan selalu mengirimkan para guru secara bergiliran untuk mengikuti pelatihan dan workshop kurikulum. Selain itu kepala sekolah juga mengadakan In House Training (IHT) dan memfasilitasi secara penuh kegiatan MGMP para guru PAI. 


\section{Implementasi Kurikulum KTSP}

Pada prinsipnya, KTSP merupakan bagian yang tidak terpisahkan dari SI, namun pengembangannya diserahkan kepada sekolah agar sesuai dengan kebutuhan sekolah itu sendiri. Pelaksanaan KTSP mengacu pada Permendiknas Nomor 24 Tahun 2006 tentang Pelaksanaan SI dan SKL.

Penyusunan silabus dan Rencana Pelaksanaan Pembelajaran merupakan tuntutan pertama yang harus dilaksanakan oleh guru dalam implementasi Kurikulum Tingkat Satuan Pendidikan (KTSP).

Langkah-Langkah Implementasi Kurikulum Tingkat Satuan Pendidikan Implementasi KTSP bermuara pada pelaksanaan pembelajaran, yakni bagaimana agar isi atau pesan-pesan kurikulum (standar kompetensi dan kompetensi dasar) dapat diterima oleh peserta didik secara tepat dan optimal. Pada umumnya pelaksanaan pembelajaran mencakup tiga kegiatan, yaitu pembukaan, pembentukan kompetensi, dan penutup.

Implementasi kurikulum KTSP mapel PAI di SMA N 1 Salatiga dan SMA Islam Sudirman disesuaikan dengan struktur kurikulum KTSP sebagaimana penjelasan Waka kurikulum dan guru PAI, maka pelajaran PAI di SMA N 1 Salatiga dilaksanakn 2 jam pelajaran perminggu disesuaikan dengan SKS (W/BDY dan MAW/IK. KTSP/26-08-2014).

Menurut guru PAI SK dan KD pada kurikulum KTSP tertuangkan semuanya pada RPP yang dibuat guru yang kemudian dijadikan acuan dan pedolaman untuk melaksankan pembelajaran di kelas (W/MAW/IK.KTSP/26-08-2014). 
Implementasi kurikulum KTSP di SMA N 1 Tengaran Kabupaten Semarang dilaksanakan sesuai dengan aturan yang ada baik mengenai jam tatap muka perminggu, materi, RPP yang di dalamnya ada penerapan SK-KD, penilaiannya, dan SKL yang di tetapkan sesuai dengan struktur kurikulum yang ada yaitu 2 jam/minggu (W/BN/IK/27 Agustus 2014).

Sedangkan tehnik metode pembelajarannya menggunakan PAKEM (pembelajaran aktif, kreatif dan menyenangkan) (O/IK KTSP/27 Agustus 2014).

Jadi Implementasi kurikulum KTSP di semua sekolah berjalan dan terlaksanakan dengan baik dari mulai penyususnan Standar isi (SI), Standar Kelulusan (SKL), penyusunan RPP dan juga pembelajaran yang dilaksanakan. Tidak ada kendala dalam pengimplementasian kurikulum KTSP, karena kurikulum ini memberikan otonomi kepada sekolah, waka kurikulum dan guru PAI untuk menyusun pembelajarannya sendiri sesuai dengan yang dibutuhkan dan kondisi yang ada sehingga pengelaola sekolah terdorong lebih kreatif dengan beracuan standar isi dan SKL. Hanya saja ada beberapa siswa yang kesulitan dalam menghafal ayat-ayat al-qur'an pada materi al-qur'an, dan waktu pembelajaran yang hanya 2 jam per minggu menjadikan pendalaman materi kurang maksimal.

Kurikulum Tingkat Satuan Pendidikan (KTSP) mengacu kepada Undang-Undang Republik Indonesia Nomor 20 Tahun 2003 (UU 20/2003) tentang Sistem Pendidikan Nasional dan Peraturan Pemerintah Republik Indonesia Nomor 19 tahun 2005 (PP 19/2005) tentang Standar Nasional Pendidikan untuk menjamin pencapaian tujuan pendidikan 
nasional dan berpedoman pada panduan yang disusun oleh Badan Standar Nasional Pendidikan (BSNP).

\section{Implementasi Kurikulum 2013}

Kurikulum 2013 pada Kompetensi Inti (KI) sebagai unsur pengorganisasi (organising element) kompetensi dasar. Sebagai unsur pengorganisasi, Kompetensi Inti merupakan pengikat untuk organisasi vertikal dan organisasi horizontal Kompetensi Dasar. Organisasi vertikal Kompetensi Dasar adalah keterkaitan antara konten Kompetensi Dasar satu kelas atau jenjang pendidikan ke kelas/jenjang di atasnya sehingga memenuhi prinsip belajar yaitu terjadi suatu akumulasi yang berkesinambungan antara konten yang dipelajari peserta didik. Organisasi horizontal adalah keterkaitan antara konten Kompetensi Dasar satu mata pelajaran dengan konten Kompetensi Dasar dari mata pelajaran yang berbeda dalam satu pertemuan mingguan dan kelas yang sama sehingga terjadi proses saling memperkuat.

Kompetensi Inti dirancang dalam empat kelompok yang saling terkait, yaitu berkenaan dengan sikap keagamaan (kompetensi inti 1), sikap sosial (kompetensi inti 2), pengetahuan (kompetensi inti 3), dan penerapan pengetahuan (kompetensi inti 4). Keempat kelompok itu menjadi acuan dari Kompetensi Dasar dan harus dikembangkan dalam setiap peristiwa pembelajaran secara integratif. Kompetensi yang berkenaan dengan sikap keagamaan dan sosial dikembangkan secara tidak langsung (indirect teaching), yaitu pada waktu peserta didik belajar 
tentang pengetahuan (kompetensi kelompok 3) dan penerapan pengetahuan (kompetensi Inti kelompok 4).

Kompetensi Dasar merupakan kompetensi setiap mata pelajaran untuk setiap kelas yang diturunkan dari Kompetensi Inti. Kompetensi Dasar adalah konten atau kompetensi yang terdiri atas sikap, pengetahuan, dan ketrampilan yang bersumber pada Kompetensi Inti yang harus dikuasai peserta didik. Kompetensi tersebut dikembangkan dengan memperhatikan karakteristik peserta didik, kemampuan awal, serta ciri dari suatu mata pelajaran. Mata pelajaran sebagai sumber dari konten untuk menguasai kompetensi bersifat terbuka dan tidak selalu diorganisasikan berdasarkan disiplin ilmu yang sangat berorientasi hanya pada filosofi esensialisme dan perenialisme.

Kompetensi Inti dan Kompetensi Dasar Sekolah Menengah Atas/Madrasah Aliyah yang merupakan satu kesatuan ide masing-masing mata pelajaran mencakup: (1) Kompetensi Inti dan Kompetensi Dasar Kelompok Mata Pelajaran Wajib, (2) Kompetensi Inti dan Kompetensi Dasar Kelompok Peminatan Matematika dan Ilmu-ilmu Alam, (3) Kelompok Inti dan Kompetensi Dasar Peminatan Ilmu-ilmu Sosial, dan Kelompok Peminatan Ilmu-ilmu Bahasa.dan Budaya.

Kompetensi Inti SMA/MA adalah sebagai berikut: · KELAS X Menghayati dan · KELAS XI Menghayati dan · KELAS XII Menghayati dan mengamalkan ajaran agama yang dianutnya. Mengembangkan perilaku (jujur, disiplin, tanggung jawab, peduli, santun, ramah lingkungan, gotong royong, kerjasama, cinta damai, responsif dan proaktif) dan menunjukkan sikap sebagai bagian dari solusi atas berbagai 
permasalahan bangsa dalam berinteraksi secara efektif dengan lingkungan sosial dan alam serta dalam menempatkan diri sebagai cerminan bangsa dalam pergaulan dunia. Memahami dan menerapkan pengetahuan faktual, konseptual, prosedural dalam ilmu pengetahuan, teknologi, seni, budaya, dan humaniora dengan wawasan kemanusiaan, kebangsaan, kenegaraan, dan peradaban terkait fenomena dan kejadian, serta menerapkan pengetahuan prosedural pada bidang kajian yang spesifik sesuai dengan bakat dan minatnya untuk memecahkan masalah.

Implementasi kurikulum 2013 sudah dilaksanakan di ke tiga sekolah yang penulis teliti, pelaksanaannya sesuai dengan struktur kurikulum 2013 dimana mata pelajaran PAI diajarkan 3 jam pelajaran perminggu dengan menyesuaikan SKS (W/WY,IK/ 25 Agustus 2014). Disamping itu, dibiasakan bagi peserta didik untuk bekerja dalam jejaringan melalui collaborative learning (W/MAW/IK/27 Agustus 2014).

Implementasi kurikulum 2013 mapel PAI di SMA Islam Sudirman Ambarawa dilaksanakan sesuai dengan aturan yang ada baik mengenai SKL, jam tatap muka perminggu, materi, RPP yang di dalamnya ada penerapan KI-KD, dan penilaian yang di tetapkan (W/RSS/IK/13 September 2014). Guru dalam melakukan pembelajaran dengan pendekatan scientific dan penilaian yang diberikanpun dengan penilaian autentik (W/MK/IK/13 September 2014).

Implementasi kurikulum 2013 pada mapel PAI di SMA N 1 Tengaran kabupaten Semarang mulai dari perencanaan guru menyusun RPP berpedoman pada permendikbud 81A, dan RPP disusun tidak untuk 
setiap pertemuan tetapi untuk 2 sampai 3 kali pertemuan. Dalam proses pembelajaran guru sudah menggunakan pendekatan scientific (W/DNS/IK/27 Agustus 2014). Dalam evaluasi guru juga sudah melakukan a). Penilaian sikap, b). Penilaian pengetahuan, c). Penilaian ketrampilan (W/DNS/IK/27 Agustus 2014). Proses pembelajaranpun dilaksanakan dengan pembelajaran PAIKEM (W/MT/27 Agustus 2014).

Jadi sebagaimana kurikulum KTSP, kurikulum 2013 yang baru diterapkan tahun pelajaran 2013/2014 di sekolah yang penulis teliti juga berjalan dan terlaksana dengan baik walau memang masih perlu pembenahan-pembenahan. Dimana kompetensi Inti menggambarkan kualitas yang seimbang antara pencapaian hard skills dan soft skills. Kompetensi kurikulum 2013 dalam pelaksanaan pembelajarannya lebih memiliki waktu lebih luas yaitu sesuai struktur kurikulum yang ada diajarkan 3 jam per minggu.

\section{Persamaan dan Perbedaan}

Dari hasil analisis penulis berdasarkan hasil wawancara dan observasi Kurikulum Tingkat Satuaan Pendidikan (KTSP) dan kurikulum 2013 memiliki persamaan yang mendasar dalam proses pengimplementasiannya, yaitu antara kurikulum KTSP dengan kurikulum 2013 sama-sama menitik beratkan kepada siswa dalam tehnik pembelajarannya (W/MAW/PPK-KTSP/25 Agustus 2014).

Menurut MT antara kurikulum KTSP dengan kurikulum 2013 sama-sama mengukur kompetensi pengetahuan, ketrampilan dan sikap, sama-sama memiliki tujuan agar siswa aktif, kreatif dan mandiri dalam 
belajar, sama-sama menginginkan guru kreatif dalam mengajar, akan tetapi kurikulum 2013 lebih menekankan pada kompetensi sikap (W/MT/PPK-KTSP-2013/27 Agustus 2014).

Adapun perbedaan kurikulum tingkat satuaan pendidikan dengan kurikulum 2013 menurut MAW adalah; Pada kurikulum 2013 siswa lebih dituntut untuk aktif dan kreatif dalam proses belajar mengajar, siswa tidak lagi semata-mata sebagai objek dalam pembelajaran namun bisa berpesan sebagai subjek dengan melakukan discoveri dan pembelajaran scientific. Selain itu kurikulum 2013 menekankan penilaian (proses) menjadi hal yang penting (W/MAW/PPK-KTSP/25 Agustus 2014). Menurut Waka kurikulum kurikulum 2013 lebih menekankan pada penilaian aspek avektif dan psikomotor dibandingkan kurikulum tingkat satuan pendidikan (W/BDT/PPK-KTSP/26 Agustus 2014).

Kurikulum 2013 bertujuan membangun landasan bagi berkembangnya potensi peserta didik agar menjadi manusia yang: a. beriman dan bertakwa kepada Tuhan Yang Maha Esa, berakhlak mulia, dan berkepribadian luhur; b. berilmu, cakap, kritis, kreatif, dan inovatif; c. sehat, mandiri, dan percaya diri; dan d. toleran, peka sosial, demokratis, dan bertanggung jawab. Sedangkan kurikulum KTSP bertujuan lebih banyak untuk meningkatkan kognitif siswa (W/RSS/PPKKTSP/13 September 2014).

Kurikulum KTSP menentukan standar isi terlebih dahulu sebagaimana dijelaskan melalui Permendiknas No.22 Tahun 2006 sudah ditentukan, SKL dijelaskan melalui Permendiknas No. 23 Tahun 2006, dan kurikulum KTSP lebih menekankan pada aspek pengetahuan atau 
kognitif. Sedangkan kurikulum 2013 menentukan SKL terlebih dahulu dijelaskan melalui Permendikbud No. 54 Tahun 2013 setelah itu baru ditentukan standar isinya, aspek kompetensi lulusan ada keseimbangan soft skils dan hard skils yang meliputi aspek sikap, ketrampilan dan pengetahuan (W/ED/PPK-KTSP/13 September 2014).

Perbedaan antara kurikulum KTSP dengan kurikulum 2013 adalah kurikulum KTSP menentukan standar isi terlebih dahulu sebagaimana dijelaskan melalui Permendiknas No.22 Tahun 2006 sudah ditentukan, SKL dijelaskan melalui Permendiknas No. 23 Tahun 2006, dan kurikulum KTSP lebih menekankan pada aspek pengetahuan atau kognitif. Sedangkan kurikulum 2013 menentukan SKL terlebih dahulu dijelaskan melalui Permendikbud No. 54 Tahun 2013 setelah itu baru ditentukan standar isinya, aspek kompetensi lulusan ada keseimbangan soft skils dan hard skils yang meliputi aspek sikap, ketrampilan dan pengetahuan (W/ED/PPK-KTSP/13 September 2014).

Perbedaan lain adalah Standar Isi (SI) dan Standar Kompetensi Lulusan (SKL) merupakan acuan utama bagi satuan pendidikan dalam mengembangkan kurikulum KTSP, sedangkan kurikulum 2013 acuan utamanya adalah Standar Kompetensi Lulusan (SKL) dan Kompetensi Inti sebagai organising element.

Perbedaan pokok antara KTSP atau kurikulum tingkat satuan pendidikan (Kurikulum 2006) yaitu berkaitan dengan perencanaan pembelajaran. Dalam KTSP, kegiatan pengembangan silabus merupakan kewenangan satuan pendidikan, namun dalam Kurikulum 2013 kegiatan pengembangan silabus beralih menjadi kewenangan pemerintah, kecuali 
untuk mata pelajaran tertentu yang secara khusus dikembangkan di satuan pendidikan yang bersangkutan. Kurikulum 2013 a). Mata pelajaran tertentu mendukung Tiap mata pelajaran mendukung semua kompetensi (Sikap, kompetensi tertentu Keteampilan, Pengetahuan); b). Mata pelajaran dirancang terkait satu dengan yang lain dan sendiri dan memiliki kompetensi dasar yang diikat oleh kompetensi inti tiap sendiri kelas; c) Bahasa Indonesia sejajar dengan Bahasa Indonesia sebagai penghela mapel lain (sikap dan mapel lain keterampilan berbahasa); d) Tiap mata pelajaran diajarkan dengan pendekatan yang sama pendekatan berbeda (saintifik) melalui mengamati, menanya, mencoba, menalar; e). Tiap jenis konten pembelajaran diajarkan terkait dan diajarkan terpisah terpadu satu sama lain Konten ilmu pengetahuan diintegrasikan dan dijadikan penggerak konten pembelajaran lainnya.

\section{Kelebihan dan Kekurangan}

kelebihan yang dimiliki KTSP adalah: Mendorong terwujudnya otonomi sekolah dalam penyelenggaraan pendidikan. Mendorong para guru, kepala sekolah, dan pihak manajemen sekolah untuk semakin meningkatkan kreativitasnya dalam penyelenggaraan program pendidikan. KTSP sangat memungkinkan bagi setiap sekolah untuk menitikberatkan dan mengembangkan mata pelajaran tertentu yang akseptabel bagi kebutuhan siswa. Penerapan KTSP merekomendasikan pengurangan jam pelajaran akan berdampak berkurang interaksi pembelajaran guru di kelas denagn peserta didik yang mengakibatkan 
kurang maksimalnya pendalaman materi yang diberikan dan kurangnya pendapatan para guru.

Kelebihan dari kurikulum 2013 antara lain: kurikulum ini membuat anak belajar secara aktif, kreatif, inovatif dan siswa menjadi berfikir mandiri serta terpupuk rasa persaudaraan yang kuat. Sedangkan kekurangannya adalah pelaksanaannya belum dapat maksimal, dan kekurangan dari kurikulum 2013 adalah sampai saat ini kurikulum 2013 belum dapat diterapkan dengan benar, sehingga murid masih banyak yang sulit memahami materi.

Selain itu kelebihan dari kurikulum 2013 adalah: a). Memberikan kesempatan kepada para siswa untuk berfikir secara kreatif; b). Siswa dapat lebih banyak mengeluarkan pendapat; c). Meningkatkan kemampuan menghafal dan konsentrasi siswa. Sedangkan kekurangannya adalah: a). Siswa cenderung kesusahan karena banyak tugas yang harus diselesaikan; b). Membuat guru terlalu santai; c). Jam belajar terlalu banyak menyita waktu. dan Kurikulum 2013 menekankan pada dimensi pedagogik modern dalam pembelajaran, yaitu menggunakan pendekatan ilmiah. Pendekatan ilmiah (scientific appoach) dalam pembelajaran sebagaimana dimaksud meliputi mengamati, (Observing) menanya (Questioning), menalar (Associating), mencoba (Experimenting) membentuk jejaring (Networking) untuk semua mata pelajaran. 


\section{Kesulitan dan Hambatan Dalam Implementasi}

Menurut beberapa nara sumber kesulitan dan hambatan dalam mengimplementasikan kurikulum KTSP dan kurikulum 2013 yang terdapat dilapangan, antara lain: dalam memberikan penilaian guru harus memberikan penilaian secara kualitatif dan deskriptif, harus banyak penunjang media dalam penerapan riilnya, dan membutuhkan banyak waktu. Selain waktu juga dalam implementasi kurikulum 2013 membutuhkan banyak biaya, karena guru harus mempersiapkan segala sesuatu yang dibutuhkan dalam proses belajar mengajar, sedangkan disisi lain gaji guru belum mampu untuk memenuhi kebutuhan yang diprasaratkan untuk memenuhi implementasi kurikulum 2013. Sehingga implementasiannyapun dengan media dan sarana seadanya yang ada dan dimiliki sekolah (W/ED/KPK-KTSP-2013/13 September 2014).

Dalam implementasi kurikulum KTSP para siswa merasa kesulitan materi penghafalan ayat-ayat alqur'an, karena ada beberapa siswa yang kesulitan ketika disuruh menghafalkan (W/PHU/ KIK-KTSP-2013/27 Agustus 2014).

Dari beberapa siswa juga kesulitan memahami implementasi kurikulum 2013 karena isi materi terlalu ribet dan terlalu dalam untuk di maknai beda dengan kurikulum KTSP yang lebih mudah dipahami (W/PHU/ KIK-KTSP-2013/27 Agustus 2014).

Untuk implementasi kurikulum KTSP kesulitan atau hambatannya adalah untuk menjabarkan materi kurang bisa maksimal karena waktunya kurang, yaitu hanya diberi 2 jam per minggu. Sedangkan untuk kurikulum 2013 terlalu banyak dokumen yang harus dipersiapkan 
sehingga menyita banyak waktu (W/MT/KHI-K.KTSP-2013/27 Agustus 2014).

Secara umum baik siswa maupun guru tidak menemukan kesulitan dalam pengimplementasian kurikulum 2013 karena materinya sangat berhubungan dengan kegiatan kehidupan sehari-hari dan ada keterkaitan antara materi yang satu dengan yang lain, hanya saja ada hambatan pada pemenuhan prasarannya yang belum sesuai (W/IWW dkk/ KHI-K.KTSP2013/27 Agustus 2014).

Dan kesulitan terpenting dari implementasi kurikulum KTSP dan kurikulum 2013 masih ada beberapa guru yang belum mampu melakukan perubahan, maka dalam mengimplentasikannyapun kesulitan untuk mencapai maksimal.

Kesulitan dan hambatan pasti ada pada setiap perealisasian segala hal tak terkecuali penerapan kurikulum, dan implementasi kurikulum 2013, diantaranya dalam memberikan penilaian guru harus memberikan penilaian secara kualitatif dan deskriptif, harus banyak penunjang media dalam penerapan riilnya, dan membutuhkan banyak waktu, hambatan yang riil lagi adalah masih banyak para guru yang belum bisa menyusun RPP dengan benar dan baik sesuai ketentuan yang ada. Keterlibatan guru yang hanya sebagaifasilitator dalam proses pembelajaran menjadikan siswa yang belum mampu menguasai materi menjadi tertinggal dari kawan-kawwannya.

Hambatan pada implementasi kurikulum KTSP adalah ketersedian waktu pembelajaran yang hanya 2 jam pelajaran per minggu menjadikan penyampean materi tidak dapat maksimal, dan kesulitan yang dihadapi 
para siswa ketika mendapatkan tugas menghafalkan ayat-ayat alqur'an, karena waktu guru untuk memberikan bimbingan sangat terbatas.

\section{Cara Mengatasi Kesulitan dan Hambatan}

Sebagaimana hasil penelitian yang penulis lakukan bahwa kesulitan dan hambatan yang dihadapi oleh instansi sekolah yang penulis teliti terdapat kesamaan dan cara mengatasinyapun tidak jauh berbeda, yaitu dengan melakukan hal-hal yang dapat mensukseskan implementasi kurikulum yang sedang diterapkan.

Langkah-langkah yang dilakukan oleh pihak instansi sekolah yang penulis teliti antara lain dengan cara pihak sekolah melengkapi segala sarana dan prasarana penunjang implementasi kurikulum baik pada waktu kurikulum KTSP maupun 2013 yang sedang berjalan, sarana tersebut meliputi: buku pokok, buku penunjang, perlengkapan ruangan belajar, seperti: audio, video, televisi walau belum semua kelas dan proyektor. sebagai wahana pembelajaran saintific pihak sekolah ada yang melengkapi laboratnya dengan laborat keimanan, yang berisi berbagai alat dan sarana kelengkapan shalat. Untuk meraih kemaksimalan dalam implentasi kurikulum pihak sekolah juga selalu mengirim guru dalam pelatihan-pelatihan dan workshop, membuat penyederhanaan materi pelajaran melalui KKG dan BKG agar siswa lebih mudah memahami materi yang disampaikan oleh guru, memberikan jam tambahan dan konsultasi akademik terhadap siswa yang merasa belum menguasai materi pelajaran, selalu memberikan penugasan penguatan dan penyuluhan kepada siswa guna menambah wawasan keilmuan, selain 
langkah-langkah akademik kepala sekolah juga selalu melakukan evaluasi terhadap kinerja guru dengan cara mensupervisi para guru guna memperbaiki administrasi pembelajaran yang dibuat para guru, maliputi: prota, promes, APP, RPP, bahan ajar yang dijadikan pegangan dan acuan dalam mengajar dan media pembelajaran yang digunakan untuk membantu pemahaman siswa dan membangkitkan motivasi siswa dalam mengikuti proses pembelajaran.

Selain mengirimkan para guru untuk mengikuti kegiatan pengembangan kompetensi pendidik di luar, pihak sekolah sendiri juga mengadakan kegiatan In House Training yang sering kali dilanjutkan langsung ke sesi workshop, pelatihan-pelatihan bahan ajar dan administrasi kelas pada lain waktu sesuai dengan plening dan jadwal yang dibuat pihak sekolah (kepala dan waka kurikulum).

\section{Kesimpulan}

Berdasarkan uraian data dan analisis yang telah dibahas pada bab empat, maka penulis dapat menyimpulkan hasil penelitian yang penulis lakukan sebagai berikut :

Implementasi kurikulum 2006/2007 (KTSP) mapel Pendidikan Agama Islam pada kajian standar kompetensi di SMAN 1 Salatiga, SMA Islam Sudirman Ambarawa dan SMAN 1 Tengaran Kabupaten Semarang tahun pelajaran 2013/2014 telah terlaksanakan dengan baik, ini dikarenakan ke tiga sekolah tersebut telah mengikuti sekaligus memenuhi garis-garis besar panduan implementasi dan struktur kurikulum yang telah ditentukan dalam Undang-Undang Republik Indonesia Nomor 20 
Tahun 2003 (UU 20/2003) tentang Sistem Pendidikan Nasional dan Peraturan Pemerintah Republik Indonesia Nomor 19 tahun 2005 (PP 19/2005) tentang Standar Nasional Pendidikan untuk menjamin pencapaian tujuan pendidikan nasional, serta hasil proses implementasi yang telah memenuhi standar kelulusan yang diprogramkan.

Implementasi kurikulum 2013 mapel Pendidikan Agama Islam pada kajian standar kompetensi di SMAN 1 Salatiga, SMA Islam Sudirman Ambarawa dan SMAN 1 Tengaran Kabupaten Semarang tahun pelajaran 2013/2014 terimplementasi dengan baik, ini dikarenakan ke tiga sekolah tersebut telah mengikuti sekaligus memenuhi garis-garis besar panduan implementasi dan sesuai dengan struktur kurikulum yang ada walaupun memang belum sempurna karena masih dalam tahap-tahap penyempurnaan. Dan Implementasi kurikulum 2013 di ke tiga sekolah tersebut pada mapel Pendidikan Agama Islam kajian standar kompetensi pada sekolah yang penulis teliti telah mangacu pada Permendikbud No. 54 Tahun 2013 yang menentukan SKL terlebih dahulu kemudian menentukan standar isinya melalui kompetemsi inti, dan pada aspek kompetensi lulusan yang diterapkan ada keseimbangan soft skils dan hard skils yang meliputi aspek sikap, ketrampilan dan pengetahuan. Pembelajaran dilaksanakan 3 jam/minggu.

Dalam implementasi kurikulum 2007 dan kurikulum 2013 mapel Pendidikan Agama Islam pada kajian standar kompetensi di SMAN 1 Salatiga, SMA Islam Sudirman Ambarawa dan SMAN 1 Tengaran Kabupaten Semarang tahun pelajaran 2013/2014 terdapat beberapa perbedaan dan persamaan. Perbedaan yang ada dalam implementasi 
kurikulum 2007 dan kurikulum 2013 mapel Pendidikan Agama Islam pada kajian standar kompetensi di satuan pendidikan yang penulis teliti yaitu pada implementasi kurikulum KTSP guru dalam menentukan Standar Kompetensi Lulusan mangacu dari Standar Isi. Standar Isi dirumuskan berdasarkan Tujuan Mata Pelajaran (Standar Kompetensi Lulusan Mata Pelajaran) yang dirinci menjadi Standar Kompetensi dan Kompetensi Dasar Mata Pelajaran, Pemisahan antara mata pelajaran pembentuk sikap, pembentuk keterampilan, dan pembentuk pengetahuan, Kompetensi diturunkan dari mata pelajaran, dan Mata pelajaran lepas satu dengan yang lain, seperti sekumpulan mata pelajaran terpisah. Sedangkan dalam implementasi kurikulum 2013 guru merumuskan Standar Kompetensi Lulusan dari kebutuhan, Standar Isi diturunkan dari Standar Kompetensi Lulusan melalui Kompetensi Inti yang bebas mata pelajaran, Semua mata pelajaran harus berkontribusi terhadap pembentukan sikap, keterampilan, dan pengetahuan, Mata pelajaran diturunkan dari kompetensi yang ingin dicapai, dan Semua mata pelajaran diikat oleh kompetensi inti (tiap kelas).

Kompetensi kurikulum 2013 yang diimplementasikan bertujuan membangun landasan bagi berkembangnya potensi peserta didik agar menjadi manusia yang: a. beriman dan bertakwa kepada Tuhan Yang Maha Esa, berakhlak mulia, dan berkepribadian luhur; b. berilmu, cakap, kritis, kreatif, dan inovatif; c. sehat, mandiri, dan percaya diri; dan d. toleran, peka sosial, demokratis, dan bertanggung jawab. Sedangkan implementasi kurikulum KTSP bertujuan lebih banyak untuk meningkatkan kognitif siswa. 
Perbedaan lain adalah Standar Isi (SI) dan Standar Kompetensi Lulusan (SKL) merupakan acuan utama bagi satuan pendidikan dalam mengembangkan kurikulum KTSP, sedangkan kurikulum 2013 acuan utamanya adalah Standar Kompetensi Lulusan (SKL) dan Kompetensi Inti sebagai organising element.

Sedangkan persamaan yang penulis temukan dalam implementasi kurikulum KTSP dengan kurikulum 2013 di satuan pendidikan yang penulis teliti antara lain: sama-sama mengukur kompetensi pengetahuan, ketrampilan dan sikap, sama-sama memiliki tujuan agar siswa aktif, kreatif dan mandiri dalam belajar, sama-sama guru kreatif dalam mengajar dan persamaan yang mendasar dalam proses implementasi kurikulum KTSP dengan kurikulum 2013 sama-sama menitik beratkan kepada siswa dalam tehnik pembelajarannya. Kekurangan yang penulis temukan adalah sama-sama belum sempurna dalam membuat RPP terutama langkah-langkah yang sesuai dengan indikator dan kompetensi yang ditentukan.

Faktor kesulitan dan hambatan yang dihadapi dalam implementasi kurikulum KTSP maupun kurikulum 2013 di antaranya adalah dalam memberikan penilaian guru harus memberikan penilaian secara kualitatif dan deskriptif pada kurikulum 2013, harus banyak penunjang media dalam penerapan riilnya, dan membutuhkan banyak waktu, hambatan yang riil lagi adalah masih banyak para guru yang belum bisa menyusun RPP dengan benar dan baik sesuai ketentuan yang ada. Keterlibatan guru yang hanya sebagai fasilitator dalam proses pembelajaran menjadikan siswa yang belum mampu menguasai materi menjadi tertinggal dari 
kawan-kawannya. Sedangkan kesulitan hambatan pada implementasi kurikulum KTSP adalah ketersedian waktu pembelajaran yang hanya 2 jam pelajaran per minggu menjadikan penyampean materi tidak dapat maksimal, dan kesulitan yang dihadapi para siswa ketika mendapatkan tugas menghafalkan ayat-ayat alqur'an, karena waktu guru untuk memberikan bimbingan sangat terbatas.

Cara yang dilakukan pihak sekolah dalam mengatasi kesulitan dan hambatan dalam implenteasi kurikulum KTSP dan kurikulum 2013 antara lain: pihak sekolah melengkapi segala sarana dan prasarana penunjang implementasi kurikulum baik pada waktu kurikulum KTSP maupun 2013 yang sedang berjalan, pihak sekolah selalu mengirim guru dalam pelatihan-pelatihan dan workshop, membuat penyederhanaan materi pelajaran melalui $\mathrm{KKG}$ dan $\mathrm{BKG}$ agar siswa lebih mudah memahami, memberikan jam tambahan dan konsultasi akademik terhadap siswa yang merasa belum menguasai materi pelajaran, selalu memberikan penugasan penguatan dan penyuluhan kepada siswa guna menambah wawasan keilmuan, dan kepala sekolah selalu mensupervisi para guru guna memperbaiki administrasi pembelajaran. 


\section{Daftar Pustaka}

Arikunto, 2002, Suharsimi. Prosedur Penelitian Pendekatan Praktik dan $R \& D$. Jakarta: Rineka Cipta.

Arikunto, 2002, Suharsimi. Prosedur Penelitian (Suatu Pendekatan Praktek). Jakarta: Rineka Cipta.

Depdiknas. 2013, Struktur Kurikulum 2013. Jakarta: P2TK Ditjen Dikti. Depdiknas. 2003,Undang-undang Nomor 20 Tahun 2003 Tentang Sistem Pendidikan Nasional. Jakarta: CV. Mini Jaya.

Hadi, Sutrisno. 2000, Metodologi Research jilid 1. Yogyakarta : Andi Offset.

Hadi, Sutrisno. 1990, Metodologi Research. Yogyakarta: PT. Andi Ofiset.

Hamalik, Oemar. 2009, Proses Belajar Mengajar. Jakarta: PT Bumu Aksara.

Hamalik, Oemar. 2003, Proses Belajar Mengajar. Jakarta: Bumi Aksara. Idi, Abdullah. 2010, Penegembangan Kurikulum Teori dan Praktik. Jogyakarta: Ar-Ruzz Media.

Kemendiknas. 2010, Peraturan Pemerintah Nomor 17 Tahun 2010 tentang Pengelolaan dan Penyelenggaraan Pendidikan. Jakarta: Karya Ilmu.

Mansur. 2001, Diskursus Pendidikan Islam. Yogyakarta: Global Pustaka Utama.

Mas'ud, 2004, Abdurrahman. Humanisme Religius sebagai Paradigma Pendidikan Islam. Yogyakarta: Gama Media.

Muhajir, Noeng. 1996, Metode Penelitian Kualitatif. Yogyakarta: Rake Sarasin.

Mulyasa, E. 2007, Kurikulum Tingkat Satuan Pendidikan: Suatu Panduan Praktis. Bandung: Remaja Rosda Karya.

Mulyasa, E. 2008, Kurikulum Tingkat Satuan Pendidikan (Konsep. Praktik. dan Implementasi). Bandung: Remaja Rosda Karya.

Moleong, Lexy J. 2010, Metode Penelitian Kualitatif. Bandung: Remaja Rosda Karya.

Nasution. 2008, Asas-asas Kurikulum. Jakarta: Bumi Aksara.

Pratt, David. 2001, Curriculum, Design and Development, New york: Harcourt Brace Javanovich.

Sugiyono, 2002, Prosedur Penelitian Kualitatif, Bandung: Remaja Rosdakarya. 
Sukmadinata, Nana Saodih. 1999, Pengembangan Kurikulum (Teori dan Praktik). Bandung: Rosda Karya.

Sukmadinata, Nana Saodih. 2003, Metode Penelitian Pendidikan. Jakarta: Rosda Karya.

Taba, Hilda, 2000, Curriculum Development:Theory anf Practice, New York: Harcourt, Brace \& World.

Yamin, Martinis. 2008, Profesionalisasi Guru dan Implementasi KTSP. Jakarta: Gaung Persada Press.

Yamin, Martinis. 2007, Desain Pembelajaran Berbasis Tingkat Satuan Pendidikan. Jakarta: Gaung Persada Press. 